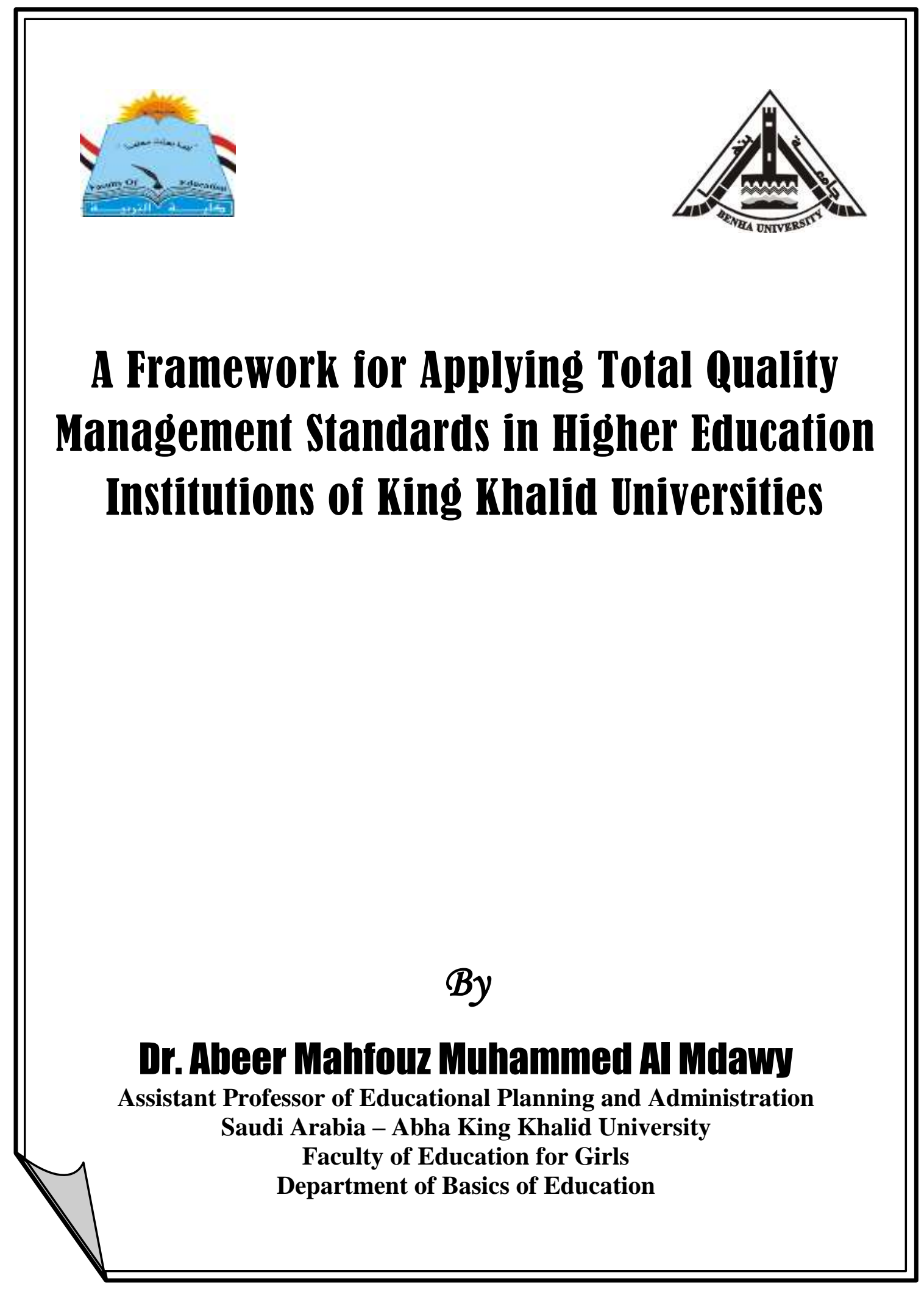




\title{
A Framework for Applying Total Quality Management standards in Higher Education Institutions of King Khalid Universities
}

\author{
By \\ Dr. Abeer Mahfouz Muhammed AI Mdawy \\ Assistant Professor of Educational Planning and Administration \\ Saudi Arabia - Abha King Khalid University \\ Faculty of Education for Girls \\ Department of Basics of Education
}

\section{Introduction:}

In this era, most countries of the world are interested in quality in educational institutions, especially developed ones as they have succeeded in applying quality in their industrial institutions. This is through improving production and goods for the customers' satisfaction. This affects directly the institution profits and its ability to compete with other industrial institutions. Therefore, there is a need to reform and develop educational institutions in light of quality as it is a global transformation from financial to intellectual investment accompanied with big changes in the demands of communities and their competition to obtain better kind of education with graduates who are able to effectively serve their community. (Al Hariri, 2010: 223)

Quality in education is one of the vital issues in the current educational system. Higher education institutions, in most countries of the world, are concerned with adopting quality as an approach. The previous programs showed limited improvement in the academic performance in schools and universities. Quality is still a controversial issue as the current educational systems in most of those countries don't efficiently prepare students for work and don't give them appropriate opportunity to show their creative abilities. (Massy, 2003: 23)

There are many reasons for adopting quality in education in higher education institutions; perhaps the most prominent reasons are the variety of goals of these institutions, expansion in the demand for university education, the emergence of new patterns of institutions in

\section{1}


addition to the expansion in private university education and the emergence of new teaching aids. All these changes encourage those responsible for the institutions to care for quality in higher education. Thus, seeking quality has become a necessity and it needs setting standards to be used for determining quality levels.

\section{Problem and Questions of the Study:}

Kada (2011: 9) assures that higher education in Algeria do not apply standards of total quality as they have problems such as: low level of educational outcomes due to lack of TQM standards that may be applied to achieve the goals. Abdu Al Shafi and El Sayed (2000:101) state that improving and developing quality are still concepts that a lot of those who work in the educational sector doubt, as they are convinced of the impossibility of doing such things because of their low financial potentiality and lack of staff that believe in quality. Therefore, they resist anything change or development in educational institutions.

Therefore, the universities of KSA rush to adopt TQM as it offers many solutions that can improve educational outcomes.

The study problem can be represented in the recognition of the application of TQM standards in higher education in KKU

The present study is an attempt to answer the following questions:

1- What are the main standards of TQM in higher education to be applied in KKU?

2- What are the differences in the participants' views about the application of TQM standards in higher education institutions according to (qualification, current position, years of experience and quality training courses)?

3- What is the framework for applying TQM standards that can improve performance level? 


\section{Goals of the study:}

1- Determining the main standards of TQM to be applied in higher education institutions in KKU.

2- Investigating the differences in the participants' views about the application of TQM standards in higher education institutions according to qualification, current position, years of experience and quality training courses.

3- Proposing a framework of TQM standards that can improve the work performance level.

\section{Delimitation of the Study:}

1- Subjective limits: This study is limited to the application of TQM standards in higher education institutions.

2- Institutional limits: King Khalid University, Abha, KSA.

3- Participants: a sample of faculty members and postgraduates in KKU (50\% for each group).

4- Duration: second term - $1435 \mathrm{H}$

\section{Methodology of the Study:}

In order to achieve the goals of the study, the researcher used descriptive / analytical method to describe the subject, analyze data and show the relationship between its components, its processes and its effects. It is a form of scientific analysis and interpretation to describe a phenomenon or special problem quantitatively through data collection classification and analysis. (Obidat et al, 2001:179)

\section{Terms of the Study:}

\section{Quality:}

Kajewski and Ritzman (2000: 88) state that quality from the provider's point of view is the matching of preset standards with the offered service, while the service quality from the customer's point of view is the suitability of this service with its use. 
The present study defines it as "the product excellence to satisfy beneficiaries' (university administration-faculty members-administratorsstudents) needs and requirements'.

\section{Total Quality:}

All the principles, policies and organizational structures which are characterized by using all the available financial and human resources so as to improve the performance and provided service and to reach the highest standard of performance and to investigate to what extent the performance and the provided service are matching the aimed standards (Emad Eddin, 2007: 122).

Oshbia (2000: 537) defines it as the total properties and characteristics that describe education accurately including all its domains such as: inputs, processes, near / far outcomes and feedback. Also, it describes the continuous interaction that leads to the achievement of certain community aims.

The present study definition of total quality is an improvement and development of all functions and activities of higher education and meet all target groups' requirements that leads to university leaders', faculty members', administrators' and students' satisfaction.

\section{Total Quality Management (TQM] Standards}

Ali (2003: 38) defines TQM standards as an approach that means the responsibility of students, references, libraries, computer centers, buildings, environment, human resources and university leaders. This approach is achieved through a whole development strategy in higher education.

The present study definition of TQM standards is Faculty members' application of quality to all elements and domains of higher education starting with planning ending with application and evaluation according to quality international standards. Taking postgraduate studies students' opinion of the extent total quality management standards are applied in King Khalid University institutions. 


\section{Higher Education Institutions:}

It's any educational institution that accept students who completed their secondary stage and got specific academic degree at the end of their high, vocational or technical education. (Diab, 2006: 17).

The present study definition of higher education institutions is Girls' faculties in KKU that accept students who completed their secondary stage with specific rates and get academic degrees when graduate.

\section{Literature and Previous Studies}

Education has witnessed great care in most countries of the world and in all fields. Reformation in education is very important as it affects progress and development of the community. It helps community to cope with renovations in the human societies. This would be done by leaders who are scientifically and practically qualified and by preparing future leadership in all fields. Also, higher education institutions face, in many Arab countries, challenges originated from changes that play a major role in changing the world, that lead to a new world which depends on science and technology. So, there is no way but applying TQ for development. This would help lots of higher education institutions to overcome their problems and weaknesses (Al Naggar, 2000:32). Universities are considered human factories that support a society for development. According to Systems theory, human forces is the university inputs after training and culturing passing by the educational process. If other commercial or industrial systems accept errors, university do not accept but total quality of education because of its effect on the whole society. (Nagm, 2010: 32).

A lot of leaders, managers, researchers and academics are interested in TQ as it is considered one of the prevailing and wanted concepts nowadays. This concept is related to the quality itself as the total properties which are concerned with the satisfaction of users' clear and complete needs. (Babkr, 2004: 105) 
Okali (2001: 23) believes that quality is producing goods or providing a service in a highly effective way according to previously set standards. It should be perfected to satisfy the customers' needs and expectations. Education quality means effective communication with students so as to acquire knowledge, skills and attitudes that enable them to satisfy beneficiaries' expectations (Hussein, 2005: 62).

So higher education service quality means continuous development and efficient performance of higher education institutions to gain society trust of graduates based on local and international standard evaluation. It also aims at effective participation between all those who work in these institutions for improving their products, services and activities so as to satisfy customs and achieve target goals leading the society benefit.

\section{Aims of Applying Quality in Higher Education}

Total quality management aims at improving productivity, beneficiaries' satisfaction and providing the best productivity and services through the continuous improvement within the organization. It also aims at workers' satisfaction and creating suitable environment for them.

Abu Al Resh (2014) summaries the aims of TQM as follows:

1- Providing job innovation, increased productivity and good performance environment.

2- Encouraging suggestions and development views to improve and develop work procedures.

3- Job satisfaction rate increases among workers.

4- Time and routine ore shorten.

5- Developing and simplify work procedures.

6- The ease of measuring workers' performance according to specific standards.

7- Heighten cooperation and integration among administrations. 
8- Training workers on group work.

9- Heighten trust and efficiency between workers and customers.

10- All workers participate in the development/ improvement processes of total quality program.

11- Going on discussions to recognize indicators of failure and success.

Abu Amer (2008:111) explains that applying quality on administrative system of university and faculties has positive effect on the educational process in all fields such as: aims and mission determination, administrative processes documentation, administrative processes analysis and development, effective communication improvement, providing suitable learning/ teaching, environment, improving the quality and efficiency of educational services, educational processes monitoring, and increasing faculty members experience through continual follow up. Total quality management is considered a comprehensive system aims at continuous improvement for the satisfaction of beneficiary and for treating and avoiding mistakes.

\section{Some Arab Counties Experiences of Applying TQM Standards in Higher Education}

\section{First: Jordanian Universities Experience}

Jordanian higher education accreditation and quality assurance commission was established by higher education and scientific research law number 4 (2005). It was established as an accreditation board of higher education institution and related to Higher Education and Scientific Research Ministry, but ambition for improving the quality of education turns it to be independent commission that is to guarantee administrative independence and flexibility. The major goals of the accreditation commission are:

1- Checking congruence between the goals of different academic programs and students' acquired skills. 
2- Checking congruence of the educational process with market requirements and economic development plans.

3- Higher education quality continuous upgrading.

4- Reinforcement of higher education courses so as to face global knowledge challenges.

In Jordan the accreditation is divided into: (1) the university general accreditation that includes: teaching staff- lab technicians accommodation - libraries - health clinics - sport playgrounds - public and private utilities;(2) academic programs special accreditation of that Includes : planning - teaching staff - assistant staff - students - booksperiodicals - encyclopedias - laboratories - equipment- tools and aids. The university is subjected to the general accreditation every three years. (Kadadh, 2007: 211).

\section{Second: The Egyptian Universities Experience}

The Egyptian government seeks higher education development as it believes that these institutions are responsible for new generations of efficient graduates that serve the society. Whenever the proportion of higher education graduates rose to the total population this is due to the nation's progress and advancement. At Al-Azhar University in 20052006, there are about 2.5 million registered students distributed among different institutions. Also Egypt has developed many projects of education quality assurance as: higher education enhancement project fund. It's a part of Cyprus convention No 4658 (2002) between Egypt and reconstruction bank to support the strategic plan of the higher education enhancement project. It's estimated by 12 million dollars, in addition to faculty members' and university leaders' capacities development project, quality assurance and accreditation project, information technology project, faculties of education project, the Egyptian technological faculties project, development project [ Strategic planning unit (SPU) and students activity project (SAP)] (Lkhdr and Ltrsh, 2010 : 79). 


\section{Third: Saudi Arabia Universities Experience}

Because Saudi Arabia is concerned with higher education quality international trends, it established independent national commission for academic accreditation and assessment that monitor higher education institutions and their programs, assess their performance and cheek their commitment to the scientific standards of specialties and academic programs. Applying quality starts from the initiation of some faculties and departments. In the $80^{\text {th }}$ of the last century some public universities in Saudi Arabia applied quality to some of their programs in agreement with international accreditation commissions as: (1) King Abdu Al Aziz University that established and developed a quality center which then became academic development and quality assurance deanship; (2) King Feisal University has developed tests for admission to ensure the quality of inputs, and then the kingdom adopted a strategy for total development of higher education through the following projects: establishing the national center for measurement and assessment and the national commission for academic accreditation and assessment. University performance quality indicator was determined by the Saudi quality board concerning: students - faculty members - administration - financial means, curricula (Mageed and Al Zaiat, 2008: 123); (3) King Saud University has established quality board which includes (measurement and assessment unit, accreditation unit, quality control unit, quality support unit, outstanding prizes unit, strategic planning unit, faculties quality unit).It also made a guide for the procedures that identify the university inputs and processes so as to improve performance, control quality and spread quality culture through meetings and workshops (King Saud University, E-site ,7/3/2008); and (4) Om Alqura University has applied quality through the administrators, academics and faculty members qualification as it provided them with workshops and training courses and gave each member a computer to improve education and research. (Om Alqura University, E-site, 14|5/2008) 


\section{The Standards of TQM Application in Higher Education}

For Al-Warthan ( 2007 : 15 ) TQ standards are all the properties and characteristics that should be provided to achieve TQ including: creating the appropriate environment, identifying the needs and requirements of the users and the strategic planning which includes (planning for quality management, planning for quality goals , planning for admission quality, planning for plans , programs and courses quality , planning for methods and educational technology quality, planning for teachers' quality, planning for buildings and equipment quality).

Higher education institutions should work according to strategic definite visions that meet the needs of the society. Adu Al Resh (2014:332-333) mentions TQM standers in higher education as:

1) Administration quality: good administration that effectively plan, organize, guide and monitor performance.

2) Programs quality: reflects university philosophy.

3) Faculty member quality: educating faculty member is very important so as to increase his efficiency and communication with students. Job safety is very necessary as it help in developing performance and achieving quality by having regulations and instructions show duties and rights.

4) Methods quality: by achieving courses goals and target outcomes.

5) Accommodation quality: Libraries equipped with modern books, laboratories equipped with modern equipment and teaching aids and classrooms wide enough.

The most important standards are: students, faculty members, curricula, university administration, financial potentialities, university and society. (Diab, 2006: 10-13). They are explained as follows: 


\section{Students:}

The learner is considered one of the most important elements in the educational process. The standards are:

1) Students selection: admission policy of university students, it is the first step in education quality in universities and making sure that there is an interaction between students and faculty members in classes, the society and curriculum activities.

2) Students / faculty members percentage: faculty members' ability to highly perform is a sign of quality in higher education. So, it must be the total number of faculty members, within reasonable limits is equal or suitable to the number of students at the least cost.

3) Average expenditure per student: where quality is measured by the rate of expenditure per student, so if the rate of expenditure in a university is more than that in another one, it is expected that quality in the university is higher than its match in the second one. Nevertheless, expenditure per student is not the only indication of quality, as money may be spent uselessly. So, students should be guided and motivated.

4) Students' services: health services, accommodation, financial aids and guidance and counseling services.

5) Students' motivation and willingness to learn. The quality of education depends on students' motivation and willingness to learn. The students' strong motivation push them towards learning, continuing and perfection

6) The ratio of graduates in each faculty: the ratio of graduates who joined postgraduate studies in a faculty.

7) The suitability of students' specialties with the needs of the society. This means that there are the adequate number and specialties that can fill the needs of the society.

8) The level of university graduates: the graduate is considered the final product of the educational process. So, this can be a sign of education quality. 


\section{Faculty Members:}

Faculty members' quality is very important. It includes the following:

1- The number of faculty members so as to cover all parts of the curriculum.

2- Faculty members' teaching competencies and their continuous development are very necessary for quality.

3- Faculty members' participation in society service.

4- Faculty members' academic training courses.

5- Faculty members' recent published researches, studies, books and articles.

6- Faculty members' full time work and academic level improvement.

7- Faculty members' participation in scientific and professional associations.

8- Faculty members' respect for their students. (Abu Hani, 2005:96)

\section{Curricula}

One of the effective factors in education quality is the origin of the programs and curriculum quality according to the level, the content, the method linked to the environment motivating to students' abilities and skills. Therefore, the curriculum should be suitable for students' present and future and concerned with their attitudes, needs and problems. Good education is the one that helps students to achieve their goals. Farah (2005:868) lists the standards as follows:

1- Course plans and annual assessment that determine work hours and days.

2- Books and additional references in university libraries.

3- Evaluation methods and tools. 
4- Buildings, utilities and equipment.

5- Educational technology, teaching aids, and educational workplaces.

6- Curriculum activities.

7- Modernity, integration and stability of in service training programs.

It also includes origin curriculum with good content that related to the real world and keep up with changes, cognitive and technology development. This can help students in their self- guidance, learning and research. Good curriculum should reinforce students' spiritual, mental, moral, cultural and scientific aspects, and prepare them for life responsibilities and experiences.

\section{University Administration:}

This is related to university research and training policy. It includes the following:

- Senior administration concern and commitment to quality.

- Human relationships among employees as faculty members perform better if there are good relationships with the department, faculty and / or university. This requires adequate communication between faculty members and the administration staff. (Ahmed,2007:159)

Therefore, the quality of administration in educational institutions depends largely on the leader. If he failed to understand the structural approach for total quality management, no success will be achieved, in addition to strategic planning quality, and activities monitoring that lead to the creation of total quality management culture (Olaimat, 2004: 114). 


\section{Financial Potentialities:}

This includes buildings, libraries, laboratories and funding as mentioned by (Diab, 2006: 13) such as:

1) University building flexibility to accommodate students' geographic location of the educational unit and its relation to the environment.

2) Faculty members' and students' library use. The library should contain specialist and non - specialist sources, books, magazines and journals. Its hours and area should be appropriate.

3) Faculty members' and students' laboratory use. The laboratories should reflect the usage of the educational programs which provided by faculties and universities. These laboratories should be supplied with necessary equipment, tools, machines and measuring tools.

4) The fund allocated to each educational institution. The success of education quality depends on the university success in gaining donations from the community in addition to funds size for students and faculty members.

El Samarai (2007: 56) assures the importance of financial means in educational institutions including furniture, laps, yards, libraries, computers, lighting and ventilation. All faculty members' and students' needs and requirements should be provided.

\section{University and Society}

Society service is considered one of the main jobs of higher education because it links scientific research with its problems so as to develop and improve the society. The standards are as follows:

1) Linking different specialties with the society needs.

2) Linking scientific research with the society problems in order to find solution for them. 
3) Interaction between the institution (with its human and research resources) with the community (with its productivity sectors). (Diab,2006:14)

\section{Previous Studies:}

\section{1) Studies That Focus on TQ Standards in Higher Education:}

1-Nughraha (2003) conducted a study entitled "Total Quality of Teaching \Learning in Higher Education". Four interviews and a questionnaire were used to determine quality indicators in American higher education. The findings were: high level of quality indicators in general. The results showed that it is necessary to focus on the students (classroom interaction) to continuously apply quality, to improve education quality. So, new technologies should be used to evaluate students. Students should work in groups to improve their decision - making skills.

2-Laurie (2004) conducted a study entitled "Moving towards Quality in Cyprus University" It aimed at investigating the workers' perception of quality environment in Cyprus University. It used the descriptive analytical curriculum. A questionnaire was applied to administrators and academics. It used Likert rating. The results revealed that university environment combines a fair, and authoritarian and advisory one. There are statistically differences between administrators' and academics' opinions in favor of administrators in the domains of official effect, cooperation, organizational structure and focusing on students. However, the differences were in favor of the academics in the domains of communication and job satisfaction. Also, there were statistically differences due to the variable of long experience.

3-Al Otaibi's Study (2006) entitled "Developing a Proposed Model of Total Quality of Kuwait University in light of leaders' and faculty members' perspectives". The study aimed at developing a proposed model of total quality management in Kuwait University in light of 
leaders' and faculty members' visions. It used the descriptive analytical curriculum. A questionnaire was applied to (1100) participants in Kuwait University. The results showed that in light of the participants opinions, the possibility of applying total quality management principles is average expect administrative affairs domain. It was high in the domain of community service. For faculty members it was average except strategic planning domain. There were no statistically differences between faculty members' opinions about the possibility of applying total quality management principles in Kuwait University due to the job variable to from a model of total quality management.

4-Asaf and Al Helw (2009) "The Reality of Quality of Graduate Programs at Al-Najaah National University as Perceived by Students." This study aimed at identifying the reality of quality of the graduate programs at Al-Najaah National University as perceived by the students. It also aimed at finding out the effect of (gender, college, level of study, students' profession, students' average, students' rout of the study on the reality of quality of the graduate programs. The population of the study consisted of (1100) students, the selected random sample was (248) students. The results showed that the graduate students had a high evaluation of the reality of the quality of the graduate programs. The main was equal to $(73 \%)$. Also, the results showed significant main of differences related to the variables of college in favor of College of Science, Sharia and College of Education. Students average in favor of excellent students whereas, there were no significant main differences due to the variables of gender, students' level and the rout of students' study thesis or comprehensive exam. Also, the study pointed out the positive and negative evaluation of the graduate programs and their suggestions to improve them.

5-Gomma (2010) conducted a study entitled "Faculty Members' Assessment of Total Quality Project in Egyptian Universities" "case study" The study aimed at recognizing the positives, negatives and 
suggestions of the total quality project in university. It used the descriptive curriculum. Results revealed that it's necessary to provide human environment that help in the university quality, and to provide communication channels between faculty members and quality units in faculties. Provide modern techniques and ways of applying and controlling quality of higher education institutions, paying attention to faculty members' training programs and relating these programs to modern necessary techniques.

6-Hamed's study (2010) entitled "Total quality management role in developing higher education institution in Khartoum state- Sudan University of Science and technology." It aimed at identifying total quality management role in the developing higher education institutions. The developing of strategic planning and the developing of faculty members' efficiency. A questionnaire was applied to (44) participants from commercial students and education faculties in Sudan University of science and technology. Results revealed that total quality management has a great rate in the development of higher education institutions, strategic planning and faculty members' efficiency. It also has a role in developing the university courses curriculum, Training based on total quality management has a role in developing Sudan University.

7-Vilgats and Heidmets (2011) conducted a study entitled "The impact of external quality assessment on university in Estonia from 1997 to 2009'.It aimed at defining the impact of external quality assessment on universities in Estonia from 1997 to 2009, studying and analyzing the reports of curriculum accreditation expert and interviews done with heads of programs and universities from 2007 to 2009. The study analyzed 12 curricula in three public universities. The study results showed that the overall impact of quality was limited despite the fact that the impact of external quality assessment was strong concerning curriculum, studying process and academic reputation of teaching units. While its impact was weak concerning university 
administration, quality assurance and funding. The study proposed some modifications to be done on quality assessment in Estonia.

8. Edres et at. (2012) conducted a study entitled "the possibility of applying total quality management to high education services for continuous improvement outcome quality assurance and accreditation obtaining". Case study - El Kharma - Al Taif University. The study aimed at identifying basic concepts of total quality management in higher education institutions, higher education services quality achievement, quality keeping and accreditation obtaining, self and external evaluation standards defining, quality culture spreading among faculty members, and their participation in all stages and all decisions. A questionnaire was applied to (132) participants from El Karma - Al Taif University (Faculty members). The study results revealed that faculty members have high awareness of the requirements of applying total quality management in higher education. It found a shortage in classrooms, laboratories, specialized libraries and university outstanding environment. Also, it found lack of students and faculty members modern methods of measuring and assessing of performance. Also, the services do not satisfy the community needs.

9. Mohammad (2014) conducted a study entitled "The availability of applying total quality management in higher education institutions in Yemen". It aimed at recognizing the extend of applying total quality management in Sana'a University and university of science and technology as perceived by faculty members and their assistants, and also identifying the relation between total quality management principles in the two universities, A questionnaire was applied to (220) participants. The study results showed that the application of total quality management is week in Sana'a University. In addition to positive correlational relations and statistically significant differences between all the principles of total quality management in both of the universities. 
10. Abu Al Resh (2004) conducted a study entitled "faculties of education total quality management reality, in Saudi Arabia universities". It aimed at recognizing faculties of education total quality management reality in Saudi Arabia universities, checking the tasks and procedures of total quality units, defining its application barriers and displaying the improvements done in these faculties. The study used an open questionnaire, interviews and field visits. The participants were (150) faculty members and administrators who work in quality units. Results showed contrast differences between faculties. In Al Taif University, faculties of education services were low as it was considered new university. Results also showed the necessity of establishing national center for accreditation and quality that all new faculties should be committed to its quality standards.

\section{Commenting on Previous Studies:}

1- The researcher benefited from the previous studies in enriching her study literature, selecting the participants and following standardized procedures such as: Asaf and Al Helw (2009), Hamed (2010), Edres et al. (2012) and Al Otaibi (2006).

2- The aims of the present study differ from the previously mentioned studies as Asaf and Al Helw's study (2009) aimed at identifying the reality of quality of the graduate programs at AlNajaah National University as perceived by the students. Nughraha and Paul's (2003) study aimed at determining quality indicators in American higher education. Laurie's study (2004) aimed at recognizing the importance of congruence between quality standards and the organization culture and the role of the conscious leader that apply TQM standards effectively. A 1 Otaibi's Study (2006) aimed at developing a proposed model of total quality management in Kuwait University in light of leaders' and faculty members' visions. Gomma's study (2010) aimed at 
recognizing the positives, negatives and suggestions of the total quality project in the Egyptian universities. Hamed's study (2010) aimed at identifying total quality management role in the developing higher education institutions. The developing of strategic planning and the developing of faculty members' efficiency. Vilgats and Heidmets' study (2011) aimed at defining the impact of external quality assessment on universities in Estonia from 1997 to 2009, studying and analyzing the reports of curriculum accreditation expert and interviews done with heads of programs and universities from 2007 to 2009. Edres et at.'s study (2012) aimed at identifying basic concepts of total quality management in higher education institutions, higher education services quality achievement, quality keeping and accreditation obtaining, self and external evaluation standards defining, quality culture spreading among faculty members, and their participation in all stages and all decisions. Mohammad's study (2014) aimed at recognizing the availability of applying total quality management in Sana'a University and university of science and technology as perceived by faculty members and their assistants, and also identifying the relation between total quality management principles in the two universities. Abu Al Resh's study (2004) aimed at recognizing faculties of education total quality management reality in Saudi Arabia universities, checking the tasks and procedures of total quality units, defining its application barriers and displaying the improvements done in these faculties. While the present study aimed at clarifying the availability of standards of total quality management that were defined by the study including: university administration, curricula associated with labor market requirements, the relation between the university and society, the satisfaction of faculty members' and students' needs as perceived by faculty members and postgraduate studies students in KKU. 
3- The present study agreed with most studies in using the descriptive curriculum such as: Laurie (2004), Asaf and Al Helw (2009), Gomma (2010), Hamed (2010), Edres et al (2012) and Al Otaibi (2006). While other studies added interviews such as: Nughraha and Paul (2003) and Vilgats and Heidmets (2011). Mohammad (2014) added comparative method. Adu Al Resh (2014) used field visits.

4- The present study was limited to some of KKU faculties of girls and its sample was faculty members as in Hamed (2010), Edres et al (2012), Mohammad (2014), Adu Al Resh (2014) and postgraduate studies students as in Asaf and Al Helw (2009).

\section{Procedures of the Study:}

The procedures of the study go as follows:

\section{Population of the Study:}

The study population consisted of faculty members and high studies students in KKU, Abha, 2014/2015

\section{Sample of the Study:}

The study sample consisted of (60) faculty members from faculty of Education and Arts (girls) in K.K.U. Abha and (61) high studies students (girls). There are statically differences between the mean estimates of the sample about the application of TQM standards in higher education according to (qualification, current position, years of experience and quality training courses). It is explained in the following:- 
Table (1): Sample Characteristics and its

Distribution on the Variables

\begin{tabular}{|c|c|c|c|c|}
\hline Variable & Variables levels & No. & Percent & Total \\
\hline \multirow{3}{*}{ Qualification } & Ph.D & 41 & 33.9 & \multirow{3}{*}{121} \\
\hline & M.A & 46 & 62.8 & \\
\hline & Bachelor & 4 & 3.3 & \\
\hline \multirow{2}{*}{$\begin{array}{l}\text { Current } \\
\text { Position }\end{array}$} & Faculty Member & 60 & 49.6 & \multirow{2}{*}{121} \\
\hline & Student & 61 & 50.4 & \\
\hline \multirow{4}{*}{ experience } & Non & 21 & 17.4 & \multirow{4}{*}{121} \\
\hline & From 1- 5 & 62 & 51.2 & \\
\hline & From 6- 10 & 18 & 14.9 & \\
\hline & & 20 & 16.5 & \\
\hline \multirow{2}{*}{$\begin{array}{l}\text { Training } \\
\text { Courses }\end{array}$} & & 45 & 37.8 & \multirow{2}{*}{121} \\
\hline & & 76 & 62.2 & \\
\hline
\end{tabular}

\section{Tool of the Study:}

The present study used the following statistical methods, means, standards deviations and Cronbach's Alpha formula to calculate the reliability coefficient of the study tool. Spearman - Brown Half - Split Formula was also used and frequencies, percentages and test were used.

\section{Reliability:}

1) Questionnaire reliability was computed using Cronbach alpha formula for the overall questionnaire. The reliability coefficient was (0.84) which was significantly high.

2) Questionnaire reliability was computed by using Cronbach Alpha for each domain, as shown in table (2). 
Table (2): Cronbach's Alpha Reliability Coefficient

\begin{tabular}{|c|c|}
\hline Domains & Cronbach's Alpha Reliability Coefficient \\
\hline \hline First: Students & 0.72 \\
\hline Second: Faculty Members & 0.58 \\
\hline Third: Curricula & 0.54 \\
\hline $\begin{array}{c}\text { Fourth: University } \\
\text { Administration }\end{array}$ & 0.81 \\
\hline Fifth: Financial Potentialities & 0.52 \\
\hline Sixth: University and Society & 0.80 \\
\hline
\end{tabular}

Table 2 shows high reliability coefficient.

3) Spearman - Brown split half was used also, as shown in table (3).

\begin{tabular}{|c|c|}
\hline Domains & Split- half reliability coefficient \\
\hline \hline First & 0.75 \\
\hline Second & 0.53 \\
\hline Third & 0.55 \\
\hline Forth & 0.75 \\
\hline Fifth & 0.5 \\
\hline Sixth & 0.77 \\
\hline
\end{tabular}

Table 3 shows high reliability coefficient.

Validity:

The questionnaire was submitted to a panel of jury $(n=15)$ specialized in the field of educational administration, psychology and curriculum and instruction at Faculty of Education (male and female), $\mathrm{KKU}$, to validate it. They were asked to check items formation and their relationships to study domains. They were also asked to omit, add or modify any necessary items. Then the researcher modified the 
questionnaire according to their suggestions. Each domain contains the following items:

(1) Students (11) items.

(2) Faculty members (11) items.

(3) Curricula (10) items.

(4) University administration (6) items.

(5) Financial potentialities (6) items.

(6) University and society (5) items.

4) Internal consistency reliability was computed by using item - to total correction, the reliability coefficient ranged from $(0.41-0.84)$ which were all statistically significant as shown in table ( 4 ).

\begin{tabular}{|c|c|}
\hline Domains & Correlation coefficient \\
\hline \hline First & 0.78 \\
\hline Second & 0.69 \\
\hline Third & 0.77 \\
\hline Forth & 0.75 \\
\hline Fifth & 0.59 \\
\hline Sixth & 0.74 \\
\hline
\end{tabular}

Table 4 shows high correlation coefficient between total scores of each domain and total scores of the overall questionnaire, these results confirm that the questionnaire is valuable.

\section{Results and Discussion:}

The present study tried to answer the following questions:

What are the main standards of TQM in higher education to be applied in KKU?

The first hypothesis says that "there are statistically significant differences between responses frequencies (high - average - low) of the application of TQM standards, the researcher used frequencies, percentages and ca 2 - test. It is explained in table (5). 
Table (5): Frequencies, Percentages and CA 2 - test

\begin{tabular}{|c|c|c|c|c|c|c|c|c|c|c|c|}
\hline Domains & & & $\%$ & & $\%$ & & \% & & & & \\
\hline \multirow{11}{*}{ Students } & 1 & 78 & 64.5 & 32 & 26.4 & 11 & 9.1 & 58.23 & $(* *)$ & 2.55 & 1 \\
\hline & 2 & 67 & 55.4 & 44 & 36.4 & 10 & 8.3 & 40.77 & $(* *)$ & 2.47 & 2 \\
\hline & 3 & 49 & 40.5 & 44 & 36.4 & 28 & 23.1 & 5.96 & $\begin{array}{l}\text { Not } \\
\text { Sig. }\end{array}$ & 2.17 & 4 \\
\hline & 4 & 22 & 18.2 & 59 & 48.8 & 40 & 23.1 & 16.97 & $(* *)$ & 1.85 & 9 \\
\hline & 5 & 55 & 45.5 & 53 & 43.8 & 13 & 10.7 & 27.8 & $(* *)$ & 2.34 & 3 \\
\hline & 6 & 41 & 33.9 & 49 & 40.5 & 31 & 25.6 & 4.03 & $\begin{array}{l}\text { Not } \\
\text { Sig. }\end{array}$ & 1.74 & 11 \\
\hline & 7 & 47 & 38.8 & 53 & 43.8 & 21 & 17.4 & 14.3 & $(* *)$ & 2.21 & 5 \\
\hline & 8 & 30 & 24.8 & 66 & 54.5 & 25 & 20.7 & 24.8 & $(* *)$ & 2.04 & 6 \\
\hline & 9 & 29 & 24 & 53 & 43.8 & 39 & 32.2 & 7.2 & $(*)$ & 1.91 & 8 \\
\hline & 10 & 22 & 18.2 & 56 & 46.3 & 43 & 35.5 & 14.6 & $(* *)$ & 1.82 & 10 \\
\hline & 11 & 26 & 21.5 & 75 & 62.2 & 20 & 16.5 & 45.1 & $(* *)$ & 2.04 & 7 \\
\hline \multirow{11}{*}{$\begin{array}{l}\text { Faculty } \\
\text { Member }\end{array}$} & 1 & 32 & 26.4 & 58 & 47.9 & 31 & 25.6 & 11.6 & $(* *)$ & 2 & 11 \\
\hline & 2 & 49 & 40.5 & 55 & 45.5 & 17 & 14 & 20.7 & $(* *)$ & 2.26 & 4 \\
\hline & 3 & 60 & 49.6 & 58 & 47.9 & 3 & 2.5 & 51.8 & $(* *)$ & 2.47 & 1 \\
\hline & 4 & 45 & 37.2 & 68 & 56.2 & 8 & 6.6 & 45.4 & $(* *)$ & 2.3 & 3 \\
\hline & 5 & 37 & 30.6 & 66 & 54.5 & 18 & 14.9 & 28.9 & $(* *)$ & 2.15 & 5 \\
\hline & 6 & 33 & 27.3 & 73 & 60.3 & 15 & 12.4 & 43.7 & $(* *)$ & 2.14 & 6 \\
\hline & 7 & 42 & 34.7 & 62 & 51.2 & 17 & 14 & 25.2 & $(* *)$ & 2.09 & 8 \\
\hline & 8 & 32 & 26.4 & 69 & 57 & 20 & 16.5 & 32.3 & $(* *)$ & 2.09 & 9 \\
\hline & 9 & 36 & 29.8 & 55 & 45.5 & 30 & 24.8 & 48 & $(* *)$ & 2.04 & 10 \\
\hline & 10 & 58 & 47.9 & $\mathbf{5 0}$ & 41.3 & 13 & 10.7 & 28.5 & $(* *)$ & 2.37 & 2 \\
\hline & 11 & 37 & 30.6 & 62 & 51.2 & 22 & 18.2 & 20.2 & $(* *)$ & 2.12 & 7 \\
\hline \multirow{6}{*}{ Curricula } & 1 & 36 & 29.8 & 71 & 58.7 & 14 & 11.6 & 40.9 & $(* *)$ & 2.18 & 2 \\
\hline & 2 & 28 & 23.1 & 73 & 60.3 & 20 & 16.5 & 40.4 & $(* *)$ & 2.06 & 7 \\
\hline & 3 & 34 & 28.1 & 68 & 56.2 & 19 & 15.7 & 31.2 & $(* *)$ & 2.12 & 4 \\
\hline & 4 & 37 & 30.6 & 62 & 51.2 & 22 & 18.2 & 20.2 & $\begin{array}{l}\text { Not } \\
\text { Sig. }\end{array}$ & 2.12 & 5 \\
\hline & 5 & 41 & 33.9 & $\mathbf{7 0}$ & 57.9 & 10 & 8.3 & 44.6 & $(* *)$ & 2.25 & 1 \\
\hline & 6 & 31 & 25.6 & 61 & 50.4 & 29 & 24 & 15.9 & $(* *)$ & 2.01 & 8 \\
\hline
\end{tabular}




\begin{tabular}{|c|c|c|c|c|c|c|c|c|c|c|c|}
\hline \multirow{6}{*}{ Domains } & & & & & & & & & & & \\
\hline & & & $\%$ & & $\%$ & & $\%$ & & & & \\
\hline & 7 & 29 & 24 & 65 & 53.7 & 27 & 22.3 & 22.9 & $(* *)$ & 2.01 & 9 \\
\hline & 8 & 27 & 22.4 & 62 & 51.1 & 32 & 26.4 & 62.3 & $(* *)$ & 1.95 & 10 \\
\hline & 9 & 31 & 25.6 & 69 & 57 & 21 & 17.4 & 31.8 & $(* *)$ & 2.08 & 6 \\
\hline & 10 & 44 & 36.4 & 52 & 43 & 25 & 20.7 & 9.5 & $(* *)$ & 2.15 & 3 \\
\hline \multirow{6}{*}{$\begin{array}{c}\text { University } \\
\text { administration }\end{array}$} & 1 & 44 & 36.4 & 56 & 46.3 & 21 & 17.4 & 15.7 & $(* *)$ & 2.19 & 3 \\
\hline & 2 & 49 & 40.5 & 48 & 39.7 & 24 & 19.8 & 9.9 & $(* *)$ & 2.2 & 2 \\
\hline & 3 & 41 & 33.9 & 54 & 44.6 & 26 & 21.5 & 9.7 & $(* *)$ & 2.12 & 6 \\
\hline & 4 & 43 & 35.5 & 61 & 50.4 & 17 & 14 & 24.2 & $(* *)$ & 2.21 & 1 \\
\hline & 5 & 43 & 35.5 & 57 & 47.1 & 21 & 17.4 & 16.3 & $(* *)$ & 2.18 & 5 \\
\hline & 6 & 45 & 37.2 & 54 & 44.6 & 22 & 18.2 & 13.5 & $(* *)$ & 2.19 & 4 \\
\hline \multirow{6}{*}{$\begin{array}{c}\text { Financial } \\
\text { Potentialities }\end{array}$} & 1 & 32 & 26.4 & 63 & 52.1 & 26 & 21.5 & 19.5 & $(* *)$ & 2.04 & 3 \\
\hline & 2 & 47 & 38.8 & 52 & 43 & 22 & 18.2 & 12.8 & $(* *)$ & 2.2 & 2 \\
\hline & 3 & 23 & 19 & 60 & 49.6 & 38 & 31.4 & 17.2 & $(* *)$ & 1.87 & 6 \\
\hline & 4 & 31 & 25.6 & 47 & 38.8 & 43 & 35.5 & 3.4 & $\begin{array}{l}\text { Not } \\
\text { Sig. }\end{array}$ & 1.9 & 5 \\
\hline & 5 & 28 & 23.1 & 59 & 48.8 & 34 & 28.1 & 13.4 & $(* *)$ & 1.95 & 4 \\
\hline & 6 & 55 & 45.5 & 48 & 39.7 & 18 & 14.9 & 19.1 & $(* *)$ & 2.3 & 1 \\
\hline \multirow{5}{*}{$\begin{array}{l}\text { University and } \\
\text { Society }\end{array}$} & 1 & 27 & 22.3 & 67 & 55.4 & 27 & 22.3 & 26.4 & $(* *)$ & 2 & 5 \\
\hline & 2 & 31 & 25.6 & 75 & 62 & 15 & 12.4 & 47.8 & $(* *)$ & 2.13 & 2 \\
\hline & 3 & 35 & 28.9 & 64 & 52.9 & 22 & 18.2 & 22.9 & $(* *)$ & 2.1 & 3 \\
\hline & 4 & 35 & 28.9 & 63 & 52.1 & 23 & 19 & 20.8 & $(* *)$ & 2.09 & 4 \\
\hline & 5 & 41 & 33.9 & 59 & 48.8 & 21 & 17.4 & 17.9 & $(* *)$ & 2.16 & 1 \\
\hline Total & & & & & & & & & & & \\
\hline
\end{tabular}

\section{Students' quality:}

\section{From table (5) it is clear that:}

1) there were statistically significant differences at level ( 0.01 ) between responses frequencies ( high - average - low ), as all ca2 values were statistically significant except statements ( $3 \& 6$ ) were not significant. For these two elements, there were no definite responses. Statement (6) got the least relative weight (1.74) 
compared to statement (3). This may be due to lack in thinking, analyzing, composing, imagining and criticizing skills among students in addition to lack of students' training on how to independently use information resources, (It is one of the modern trends of student - center education). For statement (6), it may be due to lack in students' needs and desires satisfaction to cope with up-to-date developments.

All the rest statements were significant in favor of (high average) responses. Statement (1) was the highest one as it got (64.5\%) agreement and its relative weight was (2.55). This reflects the flexibility and determination of students' admission policy according to theoretical and scientific specialties. This provides the university with students' high skills that lead to sustainable community development.

The results of the present study are consistent with the results of, Nughraha and Paul (2003), Asaf and Al Helw (2009) and Edres et al (2014) which assured the importance of students as the core of higher education. The results showed that quality components and elements should be used in designing contents related to the educational process (achievement, students' problems, teaching methods and activities), and students should be classroom interaction centered, in addition to the use of new technologies to assess students in order to get ISO.

\section{Faculty Members' quality:}

There were statistically significant differences at level (0.01) between responses frequencies (high - average - low) as all ca 2 values were statistically significant. All differences were in favor of (high average) responses. Statement (3) got the highest agreement (49.6\%) and its relative weight was (2.47). This may be due to faculty members selection policy according to their specialties, their teaching methods and their method in dealing with students, all these issues make the educational process successful and reduce education wastage rates. 
Statement (1) got the least relative weight compared to the rest. This indicates that students' admission policy is not rationed. This policy may not be based on labor market needs in addition to the wrong distribution of students per classes commensurate with faculty members' number. All this should be taken into consideration, besides students' individual differences in order to motivate students and faculty members. This is considered a barrier to the application of TQ standards in higher education.

The results of faculty members are consistent with those of Hamed (2010) and Vilgats and Heidmets (2011) which revealed that there are a lot of shortages that affect the educational inputs quality including the low level of faculty members. This assures the necessity of applying TQ standards using advanced teaching methods and providing them with new knowledge and ideas to raise the educational inputs quality.

\section{Curricula quality:}

There are statistically significant differences at level (0.01) between responses frequencies (high - average - low) as all Ca 2 values were statistically significant, except statement (4). The responses on this statement were not definite. This may be due to un-updated curricula in light of TQ standards and labor market needs, un-diversified subjects, lack of communication with society commensurate with knowledge explosion era and technological revolution. It is not useful for students to stick to a book, therefore there should be variety of subjects related to society problems through scientific visits.

All the rest were significant in favor of (high - average) responses. Statement (5) was the highest one, as its relative weight was (2.25). This may be due to students' cognitive development, high level achievement, and knowledge and skill levels. That suits scientific technology era. Statement (8) relative weight was the least, this may be because of lack of financial potentialities that provide students with good curricula with needed equipped laboratories during practicing in addition to all the 
educational facilities in order to improve the outputs quality. The results are consistent with Vilgats and Heidmets (2011) and Hamed (2010).

\section{University Administration quality:}

There are statistically significant differences at level (0.01) between responses frequencies (high - average - low) as Ca 2 values were significant. All the statements were significant in favor of (high - average) responses. Statement (4) was the highest one, as its relative weight was (2.21). This may be due to good communication between university administration and faculty members through meetings, courses and providing all their needs as tangible and moral incentives. Statement (3) was the least. This may be due to lack of training courses for admission staff. These courses would provide them with high-quality professional skills that reflect work efficiency.

The results of (university administration) are consistent with the results of Vilgats and Heidmets (2011) and Laurie (2004) which emphasized the importance of transformational leadership and top administration commitment to quality standards in higher education, the academic leadership understanding of the challenges facing the application of TQM and the importance of organizational culture in the educational institutions as an indicator of quality.

\section{Financial Potentialities quality:}

There are statistically significant differences at level (0.01) between responses frequencies (high - average - low) as all $\mathrm{Ca} 2$ values were statistically significant, except statement (4). This may be because university libraries are not supported with books or scientific journals which are useful for students and faculty members. Statement (6) got the highest agreement and its relative weight was (2.3). This may be because, the university provides electronic devices necessary for students and faculty members. Statement (3) got the least relative weight (1.87). This is because there are not enough financial potentialities to provide well- equipped building to satisfy the needs of those involved in 
the educational process. The results are consistent with Vilgats and Heidmets (2011) and Edres et al (2012).

\section{University and Society quality:}

There are statistically significant differences at level (0.01) between responses frequencies (high - average - low) as all Ca 2 values were statistically significant. Statement (5) was the highest as its relative weight was (2.16). This indicates the university concern of activating society service that leads to development and progress such as the training courses and scientific cultural programs done by the university in favor of the society. Statement (1) was the least one as its relative weight was (2), this may be due to lack of new specialties needed for labor market. There should be new specialties that serve society compared to the needs of Arab local and global universities. The results of (university and society) are consistent with the results of Edres et al. (2012) and Al Otaibi (2006) which emphasized the efforts exerted by faculties to assess, ensure and accredit quality in higher education and to apply a group of standards set by the British Quality Agency to link different specialties and scientific researches to society problems and to encourage interaction between education institutions with their human, research resources and the productivity service sectors of the society.

The second question: -What are the differences in the participants' views about the application of TQM standards in higher education institutions according to (qualification, current position, years of experience and quality training courses)?

The second hypothesis: There are statistically significant differences between the participants' views about the application of TQM standards in higher education institutions according to (qualification, current position, years of experience and quality training courses). 


\section{Qualification:}

Nova was used to test this hypothesis. This shown in table (6).

Table (6):

\begin{tabular}{|c|c|c|c|c|c|c|}
\hline Domains & Variance Source & $\begin{array}{c}\text { Sum of } \\
\text { Squares }\end{array}$ & Df & $\begin{array}{c}\text { Mean } \\
\text { Squares }\end{array}$ & $\mathbf{F}$ & Significance \\
\hline \multirow{3}{*}{ The First } & Between groups & 170.8 & 2 & 85.42 & 5.8 & $(* *)$ \\
\hline & Within groups & 1721.29 & 118 & 14.58 & & \\
\hline & Total & 1892.14 & 120 & & & \\
\hline \multirow{3}{*}{ The Second } & Between groups & 75.8 & 2 & 37.93 & 2.03 & Not Sig. \\
\hline & Within groups & 2202.39 & 118 & 18.66 & & \\
\hline & Total & 2278.26 & 120 & & & \\
\hline \multirow{3}{*}{ The third } & Between groups & 315.8 & 2 & 157.9 & 6.35 & $(* *)$ \\
\hline & Within groups & 2931.6 & 118 & 24.8 & & \\
\hline & Total & 3247 & 120 & & & \\
\hline \multirow{3}{*}{ The Fourth } & Between groups & 76 & 2 & 38 & 4.16 & $(*)$ \\
\hline & Within groups & 1077.5 & 118 & 9.13 & & \\
\hline & Total & 1153.6 & 120 & & & \\
\hline \multirow{3}{*}{ The Fifth } & Between groups & 13.5 & 2 & 6.75 & 0.84 & Not Sig. \\
\hline & Within groups & 947.3 & 118 & 8.02 & & \\
\hline & Total & 960.8 & 120 & & & \\
\hline \multirow{3}{*}{ The Sixth } & Between groups & 8.05 & 2 & 4.02 & 0.55 & Not Sig. \\
\hline & Within groups & 862.19 & 118 & 7.3 & & \\
\hline & Total & 870.24 & 120 & & & \\
\hline \multirow{3}{*}{$\begin{array}{c}\text { Overall } \\
\text { Questionnaire }\end{array}$} & Between groups & 2527.95 & 2 & 1263.9 & 4.54 & $(*)$ \\
\hline & Within groups & 32793.9 & 118 & 277.9 & & \\
\hline & Total & 35321.8 & 120 & & & \\
\hline
\end{tabular}


Table (6) shows that there were statistically significant differences at level (0.01) in the responses of participants' mean estimates according to qualification, this is for the first and third domains.

There were statistically significant differences at level (0.05) in the responses of participants' mean estimates according to qualification, this is for the fourth domain.

There were no statistically significant differences in the responses according to qualification, this is in the fifth domain.

There were statistically significant differences at level (0.05) in the responses of participants' mean estimates according to qualification, this is for overall questionnaire.

The results show the differences in participants' opinions about the application of TQM standards in higher education according to qualification.

\section{Current Position:}

$\mathrm{T}$ - test was used to check this hypothesis. Table (7) shows the results of $\mathrm{T}$ - test for (current position) variable.

Table (7): T-Test Results for the Mean Participants' Estimates (Current Position)

\begin{tabular}{|c|c|c|c|c|c|c|c|}
\hline Domains & group & $\mathbf{N}$ & Mean & \begin{tabular}{|c|} 
Std. \\
deviation
\end{tabular} & $\mathbf{T}$ & DF & Sig. \\
\hline \multirow{2}{*}{ The First (Students) } & Faculty Member & 60 & 24.45 & 4.08 & \multirow{2}{*}{2.59} & \multirow{2}{*}{119} & \multirow{2}{*}{$(*)$} \\
\hline & Student & 61 & 22.6 & 3.6 & & & \\
\hline \multirow{2}{*}{$\begin{array}{l}\text { Second (Faculty } \\
\text { Member) }\end{array}$} & Faculty Member & 60 & 22.95 & 3.17 & \multirow{2}{*}{1.45} & \multirow{2}{*}{119} & \multirow{2}{*}{$\begin{array}{l}\text { Not } \\
\text { Sig. }\end{array}$} \\
\hline & Student & 61 & 23.8 & 5.2 & & & \\
\hline \multirow{2}{*}{ Third (Curricula) } & Faculty Member & 60 & 23.01 & 5.63 & \multirow{2}{*}{3.96} & \multirow{2}{*}{119} & \multirow{2}{*}{$(* *)$} \\
\hline & Student & 61 & 19.47 & 4.07 & & & \\
\hline \multirow{2}{*}{$\begin{array}{l}\text { Fourth (University } \\
\text { administration) }\end{array}$} & Faculty Member & 60 & 14.08 & 3 & \multirow{2}{*}{3.6} & \multirow{2}{*}{119} & \multirow{2}{*}{$(* *)$} \\
\hline & Student & 61 & 12.14 & 2.9 & & & \\
\hline \multirow{2}{*}{$\begin{array}{c}\text { Fifth (Financial } \\
\text { Potentialities) }\end{array}$} & Faculty Member & 60 & 12.3 & 2.8 & \multirow{2}{*}{0.1} & \multirow{2}{*}{119} & \multirow{2}{*}{$\begin{array}{l}\text { Not } \\
\text { Sig. }\end{array}$} \\
\hline & Student & 61 & 12.26 & 2.88 & & & \\
\hline \multirow{2}{*}{$\begin{array}{l}\text { Sixth (University } \\
\text { and Society) }\end{array}$} & Faculty Member & 60 & 10.95 & 2.93 & \multirow{2}{*}{1.82} & \multirow{2}{*}{119} & \multirow{2}{*}{$\begin{array}{l}\text { Not } \\
\text { Sig. }\end{array}$} \\
\hline & Stude & 61 & 10.06 & 2.49 & & & \\
\hline \multirow{2}{*}{$\begin{array}{c}\text { Overall } \\
\text { Questionnaire }\end{array}$} & Faculty Member & 60 & \begin{tabular}{|l|}
109.7 \\
\end{tabular} & 16.58 & \multirow{2}{*}{3.11} & \multirow{2}{*}{119} & \multirow{2}{*}{$(* *)$} \\
\hline & Student & 61 & 100.3 & 16.54 & & & \\
\hline
\end{tabular}




\section{Table 7 shows that:}

There were statistically significant differences at level (0.01) in the responses of participants' mean estimates according to current position, this is for the third and fourth domains.

There were statistically significant differences at level (0.05) in the responses of participants' mean estimates according to current position, this is for the first domain.

There were no statistically significant differences in the responses according to current position, this is for the second and sixth domains.

There were statistically significant differences at level (0.01) in the responses, this is for overall questionnaire.

These results show the differences in the participants' opinions about the application of TQM standards in higher education according to current position.

\section{Years of Experience:}

To test this hypothesis, ANOVA was used. Table (8) shows the results for this variable, for each domain and overall questionnaire. 
Table (8): ANOVA Results of Participants' Mean Estimates (Years of experience

\begin{tabular}{|c|c|c|c|c|c|c|}
\hline Domains & $\begin{array}{l}\text { Variance } \\
\text { Source }\end{array}$ & \begin{tabular}{|c|} 
Sum of \\
Squares
\end{tabular} & Df & $\begin{array}{c}\text { Mean } \\
\text { Squares }\end{array}$ & $\mathbf{F}$ & Significance \\
\hline \multirow{3}{*}{ The First } & Between groups & 38.59 & 3 & 12.86 & 0.81 & Not Sig. \\
\hline & Within groups & \begin{tabular}{|l|}
1853.55 \\
\end{tabular} & 117 & 15.8 & & \\
\hline & Total & 1892.14 & 120 & & & \\
\hline \multirow{3}{*}{ The Second } & Between groups & 36.5 & 3 & 12.17 & 0.63 & Not Sig. \\
\hline & Within groups & 2241.73 & 117 & 19.16 & & \\
\hline & Total & 2278.26 & 120 & & & \\
\hline \multirow{3}{*}{ The third } & Between groups & 219.2 & 3 & 73 & 2.82 & $(*)$ \\
\hline & Within groups & 3028.2 & 117 & 25.8 & & \\
\hline & Total & 3247.5 & 120 & & & \\
\hline \multirow{3}{*}{ The Fourth } & Between groups & 36.45 & 3 & 12.15 & 1.27 & Not Sig. \\
\hline & Within groups & 1117.15 & 117 & 9.5 & & \\
\hline & Total & 1153.6 & 120 & & & \\
\hline \multirow{3}{*}{ The Fifth } & Between groups & 6.09 & 3 & 2.03 & 0.25 & Not Sig. \\
\hline & Within groups & 954.78 & 117 & 8.16 & & \\
\hline & Total & 960.87 & 120 & & & \\
\hline \multirow{3}{*}{ The Sixth } & Between groups & 24.5 & 3 & 8.17 & 1.13 & Not Sig. \\
\hline & Within groups & 845.73 & 117 & 7.22 & & \\
\hline & Total & 870.24 & 120 & & & \\
\hline \multirow{3}{*}{$\begin{array}{c}\text { Overall } \\
\text { Questionnaire }\end{array}$} & Between groups & 1074.4 & 3 & 358.13 & 1.22 & Not Sig. \\
\hline & Within groups & 3427.4 & 117 & 292.7 & & \\
\hline & Total & 35321.8 & 120 & & & \\
\hline
\end{tabular}

\section{Table 8 shows that:}

There were statistically significant differences at level (0.05) in the responses of participants' according to years of experience, this is for the third domain.

There were statistically significant difference at level (0.05) in the responses of participants' mean estimates according to qualification; this is for the fourth domain. 
The results show that there were no differences in the participants' opinions about the application of TQM standards in higher education according to years of experience except for the third domain (Curricula) according to years of experience.

\section{Quality Training Courses:}

To test this hypothesis, T- test was used. Table (9) shows the result of this variable for each domain and overall questionnaire.

Table (9): T- test Results of the Participants' Mean Estimates (Training)

\begin{tabular}{|c|c|c|c|c|c|c|c|}
\hline Domains & Training & $\mathbf{N}$ & Mean & $\begin{array}{c}\text { Std. } \\
\text { deviation }\end{array}$ & $\mathbf{T}$ & DF & Sig. \\
\hline \multirow{2}{*}{$\begin{array}{l}\text { The First } \\
\text { (Students) }\end{array}$} & $\overline{\sqrt{ }}$ & 45 & 24.02 & 3.9 & \multirow{2}{*}{1.05} & \multirow{2}{*}{119} & \multirow{2}{*}{$\begin{array}{l}\text { Not } \\
\text { Sig. }\end{array}$} \\
\hline & $\mathrm{X}$ & 76 & 23.2 & 4 & & & \\
\hline \multirow{2}{*}{$\begin{array}{l}\text { Second (Faculty } \\
\text { Member) }\end{array}$} & $\sqrt{ }$ & 45 & 24.44 & 3.5 & \multirow{2}{*}{0.14} & \multirow{2}{*}{119} & \multirow{2}{*}{$\begin{array}{l}\text { Not } \\
\text { Sig. }\end{array}$} \\
\hline & $X$ & 76 & 24.32 & 4.7 & & & \\
\hline \multirow{2}{*}{ Third (Curricula) } & $\sqrt{ }$ & 45 & 21.8 & 3.68 & \multirow{2}{*}{1.07} & \multirow{2}{*}{119} & \multirow{2}{*}{$\begin{array}{l}\text { Not } \\
\text { Sig. }\end{array}$} \\
\hline & $\mathrm{X}$ & 76 & 20.8 & 5.9 & & & \\
\hline \multirow{2}{*}{$\begin{array}{l}\text { Fourth (University } \\
\text { administration) }\end{array}$} & $\sqrt{ }$ & 45 & 13.82 & 2.95 & \multirow{2}{*}{1.97} & \multirow{2}{*}{119} & \multirow{2}{*}{$\begin{array}{l}\text { Not } \\
\text { Sig. }\end{array}$} \\
\hline & $X$ & 76 & 12.68 & 3.12 & & & \\
\hline \multirow{2}{*}{$\begin{array}{c}\text { Fifth (Financial } \\
\text { Potentialities) }\end{array}$} & $\sqrt{ }$ & 45 & 12.02 & 2.88 & \multirow{2}{*}{0.79} & \multirow{2}{*}{119} & \multirow{2}{*}{$\begin{array}{l}\text { Not } \\
\text { Sig. }\end{array}$} \\
\hline & $\bar{X}$ & 76 & 12.44 & 2.80 & & & \\
\hline \multirow{2}{*}{$\begin{array}{l}\text { Sixth (University } \\
\text { and Society) }\end{array}$} & $\sqrt{ }$ & 45 & 10.37 & 2.9 & \multirow{2}{*}{0.39} & \multirow{2}{*}{119} & \multirow{2}{*}{$\begin{array}{l}\text { Not } \\
\text { Sig. }\end{array}$} \\
\hline & $\mathrm{X}$ & 76 & 10.57 & 2.56 & & & \\
\hline \multirow{2}{*}{$\begin{array}{c}\text { Overall } \\
\text { Questionnaire }\end{array}$} & $\sqrt{ }$ & 45 & 106.5 & 16.0 & \multirow{2}{*}{0.76} & \multirow{2}{*}{119} & \multirow{2}{*}{$\begin{array}{l}\text { Not } \\
\text { Sig. }\end{array}$} \\
\hline & $\mathrm{X}$ & 76 & 104.1 & 17.84 & & & \\
\hline
\end{tabular}

Table 9 shows that there were no statistically differences in the responses according to training, this is for all domains and overall questionnaire.

These results indicate that there were no differences in the participants' opinions about the application of TQM in higher education according to training.

According to the previously discussed results and the study questions, the researcher believes that the answers of the study questions 
revealed the importance of applying TQM standards in higher education. TQM standards should be applied in all higher education institutions to achieve educational quality by having high efficient leaders, qualified faculty members, students who have the ability to learn new skills and information, updating curricula to suit students' and society needs, creating environment that encourage continuous learning, and strengthen the relation between the university and society.

\section{The third question:}

What is the framework for applying TQM standards that can improve performance level?

The proposed framework relies on basics of applying TQM standards and their interaction and integration with factors and challenges affecting higher education development. It is as follows:

a) Saudi society has to achieve educational, social and economic requirements and encourage competition and creation to meet global challenges and transformations.

b) Developing university administrative structures and work mechanisms to achieve performance and outcomes quality.

c) Proposing a framework for developing the university inputs, processes and outcomes to integrate effectively between ideas and possibility of application.

d) Applying TQM standards would help in solving higher education development problems.

Therefore, the following procedures are necessary to succeed in applying TQM standards:

1- Quality culture and concepts should be widely spread to those who work in higher education institutions in order to create environment that ready to accept TQM requirements that may be through meetings and training courses.

2- Long term strategic planning of quality programs. 
3- Benchmarking university programs with other similar programs of pioneer global universities.

4- Showing more interest in communications network and internet because of their importance in enriching education and motivating students and faculty members to go on searching.

5- Developing, supporting and treating weaknesses through using computer in education, motivating workers to work efficiently and developing curricula and plans according to labor market needs and developments.

6- Setting certain standards to assess education quality by adoption of benchmarking with pioneer local, national and global universities and applying them regularly on faculty members, administrative staff, students, programs and curricula.

7- Studying the possibility of applying ISO specifications on the university and reviewing Arab and global experiences concerning this field.

8- Forming internal and external assessment teams from different faculties to check the application of quality in higher education.

9- Encouraging faculty members and administrators to participate in conferences, forums and scientific workshops so as to heighten their efficiency, academic and administrative positions. This would positively reflected on quality level in higher education.

10- Studying the possibility of applying ISO specifications on the university and reviewing Arab and global experiences concerning this field.

11- Curricula and plans continuous development in light of scientific, cognitive and technological developments in all specialties and according to community and labor market needs. 


\section{References}

- Abd Al Shafi, Ahmed Abd Al Hamid Wanas, and El Sayed Mohammad (2000): Quality Culture in Japanese Education and Administration and Possibility of Making use of it in Egypt. Journal of Education. Published by The Egyptian Association of Comparative Education and Administration. Vol, 2.No, 1.

- Abu Al Resh, Radwan Hamed (2014): The Reality of Total Quality Management in Faculties of Education in Kingdom of Saudi Arabia. Journal of Education, No.1.

- Abu Amer, Amal Mahmoud (2008): The Reality of Administration Quality in Palestinian Universities as Perceived by Administrators and its Development. Unpublished Master Thesis. Faculty of Education. Islamic University. Gaza. Palestine.

- Abu Farah, Youssef Ahmed (2005): Application of Total Quality Management in Higher Education Institutions. The fifth Conference of Higher Education Quality from 11 to 13| 4| 2005. Faculty of Education. Bahrein University. Bahrein.

- Abu Hani, Atah (2005): Total Quality Management in Education. The Monthly Meeting of Managers and Supervisors. Al Katan Centre for Educational development and Research. Gaza. Palestine.

- Ahmed, Hafez (2007): Total Quality in Educational Institutions. $1^{\text {st }}$ Edition. Alam Alkotob. Cairo. Egypt

- Al Hariri, Rafed Omar (2010). Leadership and Quality Management in Higher Education. Dar Al Thakafa for Printing and Publication. $1^{\text {st }}$ Edition. Amman, Jordan. 
- Al Otaibi, Noaf Mohammad (2006): A Proposed Model for Total Quality Management in Kuwait University in Light of Leaders' and Faculty Members' Perspectives and Possibility of Application. Unpublished Doctoral Proposal. Amman University. Amman. Jordan.

- Ali, Ali Hussein (2003): "The Issue of Modernization in Higher Education in the Arab Republic of Egypt" Available online at: http: //www.khayma.com/education-technology/s1.htm. Retrieved on: 10 Jan 2004

- Al Naggar, Farid (2000): Universities Management by Total Quality. Dar Ezak for Publication Jordan.

- Al-Warthan, Adnan Ahmed (2007): The Level of Teachers' application of the Total Quality Standards in Education: A Field Study in Al-Ahsa Province, A Research Presented in The Fourteenth Annual Meeting of the Saudi Association for Education and Psychology (GESTEN): Quality in Public Education 28-29 other spring 1428 / 15-16 / 2007.

- Asaf, Abdu, Al-Helw, Ghassan (2009): The Reality of Education Quality in the Postgraduate Programs at Al-Najaah National University, from the Students' Perspectives, Journal of Al-Najaah National University, Vol. 23, No. 3

- Babker, A. (2004). Higher Education in the Arab Region: Some Trends and Challenges. Available at::http://www.upc.es/catala/notices/arxiuarxiu2004/cnferences/ab dulghani.pdf

- Diab, Sohail Rizk (2006): Quality Indicators and Its Use in Organizing Teaching and Learning, Quality in Higher Education, Vol. 2, No. 1 
- Edres, Abdulah Mosa et al. (2012). The possibility of Applying Total Quality Management to Higher Education Services for continuous Improvement, Outcomes quality and Accreditation Obtaining. Case study-Al Kharma- Al Tiaf. Amarabac Journal American Arab Academic Journal for Science and Technology. Vol. 3, No. 7

- El Samarai, Mahdi (2007): Total Quality Management in Productive and Service Sectors. $11^{\text {th }}$. Dar Gareer for Publication. Amman. Jordan

- Emad Eddin, Ali Shaban (2007): "Total Quality and Accreditation Systems in Universities in Light of International Standards," A Paper Presented in the Fourteenth Annual Meeting of Saudi Association for Education and Psychology (GESTEN): Quality in Public Education 28-29 Rabi 1328 AH / May 15 to 16 Al Qassim $28-29 / 4 / 1428$.

- Gomma, Fatma Ali Al Saed (2010): Faculty Members' Evaluation of Total Quality in Egyptian Universities. Case Study. Journal of Arab Education Future. Vol. 17

- Hamed, Gadah Ebeed (2010): The Role of Total Quality Management in Development Higher Education Institutions in Al Khartoum State- Sudan University for Science and Technology. Unpublished Doctoral Thesis. Faculty of Education. Sudan University for Science and Technology. Al Khartoum. Sudan

- Hussein, Salama Abd Al Azeem (2005): Quality Assurance and Accreditation in Education. Dar Al Sawtaih. Riyadh. Saudi Arabia.

- Kada, Yazed (2011). The Reality of Applying Total Quality Management in Algerian Educational Institutions. Unpublished Master Thesis. Faculty of Economy and Commerce. Abu Bakr Blkaid University. Talmsan. Algeria. 
- Kadadh, Isa Youssef (2007): A proposed Model for Using Total Quality Management to Achieve High Value of Private Jordanian Universities. Journal of Human Sciences, Vol.5, No.35.Amman. Jordan.

- King Suad University (2008): E-Site 3/7/2008 Retrieved from: http://www.ksu.edu.sa/sites/admindepts/development/aspx.stroc$\underline{\text { ture/pages }}$

- Krajewsk, L. and Ritzman, P. (2000). Operations Management: Strategy and Analysis. Don Mills, Ontario, New York: AddisonWesley Publishing Company.

- Laurie, L. (2004). Embedding Quality: The Challenges for Higher Education. Quality Assurance in Education, 12(4),157-165.

- Lkhdar, Sadaa'a and Latrsh, Mohammad (2010): Total Quality Management in Services Sector. Matoniry University. Algeria

- Majeed, Sawsan Shaker and Al Zaiat Mohammad Auad (2008): Quality in Education. Dar Sana'a for Publication. 1st Edition. Amman, Jordan.

- Massy, W. (2003). Honoring the Trust. Quality and Cost Containment in Higher Education. New York: Anker Publishing.

- Mohammad, Abd Al Latif Moslh (2014): The availability of Applying Total Quality Management in Higher Education in Yemen. Arab Journal of Higher Education Quality Assurance. Faculty of Science and Technology. Vol. 7, No. 16. Sana'a. Yemen

- Nagm, Aboud Nagm (2010): Total Quality Management in Internet Age, Dar Safaa, Amman. Jordan. 
- Nughraha, P. (2001). Management in Teaching \& Learning Process (Online). Available at: http://www.Petra.ac.id/english/science/tqm/paper5hlm

- Okali, Omar (2001): Integrated Methodology for Total Quality Management "point of view". $1^{\text {st }}$ Edition, Dar Wael for Printing and Publication. Amman.

- Olimat, Salah Nasser (2004): Total Quality Management in Educational Institutions. Application and Development Suggestions. 11th Edition. Dar Al Shrouk for Publication. Amman. Jordan

- Om Alqura University (2008): Retrieved from: http://www.alazhar.edu.ps/Arabic/venters/quality unit/qu.htm

- Oshbia, Fathi Darwish (2001): Total Quality and the Possibility of Its Application to the Egyptian Higher Education: Analytical Study. Journal of Arab Universities Union, No.3.

- Vilgats, B. and Heidmets, M. (2011). The impact of External Quality Assessment on Universities: The Estonian Experience. Higher Education Policy, Vol.24, No.3. 